\title{
Making Students the Principal Focus in Institutional Management of Public Universities in Ghana: A Vehicle for Quality Assurance
}

\author{
Patrick Reeks \\ University of Education, Winneba, P. O. Box 25, Winneba, Ghana \\ *E-mail: patreeks@uew.edu.gh
}

\begin{abstract}
This paper enumerates some cases of student unrest in public universities in Ghana, and posits that the frequency of demonstrations and its attendant disruption of academic work is largely attributable to the antiquated institutional management practices where student influence in university governance is marginalized. The background reasons why the public universities are managed without much recourse to student views are examined; for example, the assertion that student satisfaction cannot be seen as an indication of good quality university education. Again, some current developments in university education in the country which necessitates the need for public universities to focus on student views in institutional management are outlined; for example, financial demands on students for which students are entitled to demand value for money. Based on the foregoing issues, measures that may be taken to ensure quality in university education by making students the principal focus in institutional management are discussed. The paper concludes that university students should be allowed to make greater contributions to policies that affect their education, and that policies and funds in public universities in Ghana should be directed in more student-centred ways.
\end{abstract}

Keywords: Public universities, student demonstrations, institutional management, educational process, quality assurance, student-centred, student views.

DOI: $10.7176 / \mathrm{JEP} / 13-4-01$

Publication date: February $28^{\text {th }} 2022$

\section{Introduction}

Quality university education is, in essence, reflected in the extent to which student needs are met, but when institutional policies go against student aspirations, there is tendency for students to embark on protests. In line with this, Aluede, et. al. (2005) observe that a topmost issue that precipitates student unrest in recent times is students' non-participation in decision making processes in the universities. They accordingly state that "the degree of students' involvement in the decision-making processes has been recognized to be inversely related to the frequency of student unrest." (p. 19). Likewise, Luke Martell of University of Sussex, in a discourse on student protest cited in Shaw (2013), posits that "When choices are made about the University's future, staff, students and their unions should be meaningful citizens and partners", but "when procedures feel rigged, no wonder people resort to action outside governance structures". "It is inevitable people look for other ways to make their voices heard" (p. 1). Admittedly, these observations affirm the contention that student demonstrations are at least, in part, attributable to marginalization of student views in institutional management.

In Ghana, student demonstrations are not uncommon phenomena in public tertiary institutions, though same cannot be said about private tertiary institutions in the country. Instances of some recent student demonstrations are the following: In March, 2021, disgruntled students of the Ghana Institute of Journalism massed up at the Institute's Campus to protest against what they termed an "insensitive directive from Management, asking those who paid their fees after the registration deadline to defer their course". ("GIJ students protest", 2021); In January, 2021, students of the University of Ghana, Legon staged a protest against Management's decision to implement a 'double-track' academic calendar. This policy, the students claimed was proof that "management clearly doesn't care about our opinions". (Antwi, 2021); In March, 2019, students of the University of Education, Winneba (UEW) disrupted academic work and destroyed university property in a protest against a decision by the Governing Council to dismiss some lecturers; In October, 2018, students at Kwame Nkrumah University of Science and Technology mounted road blocks, vandalised property and boycotted lectures in protest against actions of University Management. The students claimed that university authorities brutalized them after Management accused them of engaging in illegal activities. ("Demonstrating KNUST students", 2018). Besides these actual demonstrations, several threats of demonstration had been suppressed or barred by injunction within the past few years. The contention of this paper is that if students were sure that their grievances would be heard and addressed through dialogue, they would not resort to demonstrations and the use of arms. But the situation in public universities in Ghana is that they seem to remain largely managed in ways which reflect primarily the aspirations of academic staff, such that the views and expectations of students are usually of little or no consequence in Management decisions. Students may be scantily represented at the Governing Council level and on other Boards and Committees, but they are usually not given the same audience as is given to their lecturers and senior administrators on the Boards or Committees. In fact, a typical set-up of a public university Board 
could be seen as an intimidating environment for student representatives, especially because the student numbers on the Boards are often scanty. For example, the Governing Council of the University of Cape Coast (UCC) has 22 members with only two student representatives, and that of UEW has 21 members with only two student representatives, and in both universities the Finance Committee and the Development Committee have no student representation. (UCC Statutes 2016; UEW Statutes, 2020). In view of this, policies formulated and implemented in the public universities in Ghana are sometimes in conflict with student aspirations, and this becomes the catalyst for demonstrations. It is against this background that this paper sets out to explore ways by which students could be seen as customers or clients of the universities such that university policies may be designed to primarily serve the interest of students.

\section{Why Public Universities in Ghana Typically Disregard Student Views in Institutional Management}

By tradition, public universities in Ghana are typically managed without much recourse to student views for the following reasons:

First, university education in Ghana was free from inception until the latter part of the 1990s. Dogbevi (2008) affirms that public universities in Ghana continued to offer free education until 1998 when government decided to withdraw grants which covered students' Academic Facility User Fees and Residential Facility User Fees. In fact, government funding of tertiary education started in 1948 when the University College of Ghana, now University of Ghana, was established, and this continued when a second public university, Kumasi College of Technology, now Kwame Nkrumah University of Science and Technology, was established in 1952. Even as additional public universities were established after independence in 1957, the financial cost of university education continued to be virtually borne by the government for another four decades. Besides, for most part of the period when university education was virtually free, university students were mostly direct entrants from secondary schools - young, uniform, and inherently submissive - seeking first degrees. Thus, given the nature of university students during the early years of the establishment of universities in Ghana, and the fact that university education, including feeding, was free, it stands to reason that universities, from the outset, did not have cause to consider students as partners in decision making.

Second, public universities in Ghana are usually preferred choices because most of them have gained status and prestige over the years. Marginson (1998), cited in Coaldrake (2001), argues that "market competition in higher education is influenced by the nature of higher education as a positional good." (p. 77). This is interpreted to mean that the value of university education is often relative rather than absolute, and it is perceived value rather than intrinsic quality which guides student choice, and even employers' recruitment selections. Simply put, when it comes to higher education, quality tends to be determined by the perceived status of the university, rather than status determined by actual quality. Thus, with the overriding objective of obtaining prestigious degree certificates, students in Ghana will prefer education at public universities even if such universities pay less attention to providing quality educational processes. This partly explains why the public universities in Ghana are usually over-subscribed in spite of evidence of suboptimal attention to student needs. And, on this account, there seem to be no urgent need for these universities to act in ways to attract more prospective students.

Third, students are not considered by public universities as clients or customers as in businesses. In businesses, entrepreneurs or managers deal with clients, consumers or customers by pandering to their demands because consumer satisfaction is key to the survival of the business. The application of this principle in university education is however rejectable because in university education, student satisfaction cannot be seen as synonymous with good quality educational processes. In view of this, public universities often explicitly or implicitly do not accept the designation of students as customers or clients, and they continue to operate without much recourse to student views with the presumption of protecting quality, ensuring academic autonomy, and ensuring best educational interest of students. This presupposes that allowing emphasis on students' expressed preferences in institutional policies could compromise standards.

\section{Why Public Universities Should Pay More Attention to Student Views in Institutional Management}

The reasons just discussed about why public universities in Ghana often do not pay much attention to student views in institutional management are contentious, particularly in the face of contemporary dynamics in university education in the country. Over the past couple of decades, the public universities in Ghana have seen progressive financial demands on students, increasing competition with private universities, and remarkable diversity in the student body. These developments, as discussed below, justifiably require managers of the public universities to abandon any antiquated management practices and pay more attention to student views - as a reflection of student needs - in formulating policies that affect students.

\subsection{Financial Demands on Students}

Public universities in Ghana are no longer offering free education. Over the past two decades, dwindling public funding has compelled universities to require students to contribute to the funding of their education. Dogbevi 
(2008) attests that in 1992 the government of Ghana declared in a white paper that "... government alone cannot continue to bear the increasing cost of higher education and therefore, there was the need for cost sharing by all stakeholders." , and in 1998 students of public universities were asked to pay for Academic Facility User Fees and Residential Facility User Fees. According to Adu (2009), a study found that government of Ghana support per university student, in real terms, decreased by about $75 \%$ in the $1990 \mathrm{~s}$. Thus, throughout this period, students had been compelled to progressively take on large and larger share of the burden of financing university education. Currently, students in public universities are made to pay fees beginning from application for admission, throughout the period of study, and for graduation. And this action of public universities in making huge financial demands on students seem to be justified by the emergence of private universities that charge high fees, though they usually do not have as much infrastructure and experienced instructors as the public universities. But private universities are noted for offering special treatment to their students. Slaughter and Leslie (1999) affirm that since tuition fees constitute the major part of institutional revenues of private colleges and universities, students are treated as important clients, in stark contrast with student treatment in public universities. To wit, whereas the private universities strive to ensure provision of competitive quality and value for money services, the public universities are still characterized by deficiencies in attention to student needs in spite of increasing rates of financial demands on students. It is therefore simply a matter of fairness that public universities in Ghana should also strive to ensure provision of competitive quality and value for money services by focusing on student views and feedback.

\subsection{Competition from Private Universities}

The growth of the private sector universities has been a prominent feature in Ghana over the past couple of decades. Following the national accreditation of Valley View University, a private institution established by the Seventh Day Adventist Church in 1995, many other private entities, particularly religious bodies, have invested in the establishment of universities in the country. Data provided by Kamram et. al. (2019) indicate that, as at 2019, there were 81 accredited private higher education institutions in Ghana, and four of them - Ashesi University, Central University, the Trinity Theological Seminary and Valley View University - were already chartered as independent degree-granting institutions. The Ghana Tertiary Education Commission (2021) also provides data that shows that as at March 2021, there were seven 'chartered private tertiary institutions' and 73 other 'private tertiary institutions offering HND/degree programmes' in the country. These private universities and university colleges are typically 'for-profit' institutions that rely heavily on student fees as their source of finance, and therefore treat their students as clients. They usually offer programmes in market oriented subject areas in the most convenient ways to students. Statistics provided by UNESCO, cited in Kamram, et. al. (2019), further shows that the proportion of Ghanaian tertiary students enrolled in private institutions increased from 13 percent to 20 percent between 2007 and 2012. Again, data provided by the Ghana National Council of Tertiary Education (2018) shows that in the 2016/2017 academic year, 258,699 students enrolled in the existing nine public universities, whereas 66,022 students enrolled in 74 private tertiary institutions, indicating that the private tertiary institutions had 20 percent share in student enrolment in relation to public universities. From the foregoing trend, it is obvious that public universities no longer have monopoly in providing higher education in Ghana; they are in competition with private universities. Thus, in the face of the current competition with private universities, public universities stand to lose respect and patronage if they do not adopt measures to improve quality and ensure student satisfaction. The assertion that students will still pursue education at public universities for status reasons would not hold forever. If public universities continue to be complacent and do not improve, the realities of quality will eventually erase people's perceived high value for these universities, and higher education would subsequently replicate the situation of basic education in Ghana where many parents prefer private schools to public ones for their wards.

\subsection{Diversification of Student Body}

Universities have become lifelong learner market, focusing attention on the education and training of both young persons and adults. In accordance with this trend, Ghanaian public universities have seen increasing adult student enrolments over the years, augmenting the traditional young persons who enter university directly from secondary schools. The undergraduate student body, which a couple of decades ago was almost entirely made up of young people of ages around 20 years, currently has a significant proportion of older people, often referred to as 'mature students'. Universities in Ghana define 'mature student' as a student who was at least 25 years old at the time of applying for admission, and who gained admission by passing a special entrance examination organized by the university. At the University of Education, Winneba, for example, the admission policy allows up to $30 \%$ concession for mature applicants. Besides, most public universities are running post-diploma and postgraduate programmes, usually pursued by older persons, some already in paid employment who attend university due to the need to continually develop new skills to stay abreast with developing trends. Then again, there is the situation of increasing number of international students, some of whom are on exchange programme 
from reputable foreign universities. For example, in the 2019/2020 academic year, out of 18,212 students who enrolled to pursue various programmes at the University of Ghana, Legon, 3,045 were graduate students and 409 were international students. ("University of Ghana", 2019). While this diversity of the student body makes a university stronger in terms of international recognition and income generation, it also has implication on management practices. Older, or 'mature' or 'learner-earner' students cannot be treated as 'submissive' students, and international students cannot be treated as traditional students. These 'new' categories of students usually have heightened expectations in their pursuit of university education; they usually expect universities to provide them with quality education in ways which are convenient and which befit their status and standing. It is therefore important that public universities in Ghana make provisions for such students to play active and valued roles in the formulation of policies that affect their education.

\section{Contemporary Student Expectations in Institutes of Higher Learning}

In view of financial demands on students, competition among universities, and diversification of student body just discussed, public universities need to be more responsive to their students' needs. Some obvious needs and demands of present-day students in tertiary education are the following:

- High quality teaching from their lecturers in terms of content and modes of delivery.

- Conducive university environment for teaching and learning, including adequate and suitable infrastructure and equipment.

- Curricula that is relevant in professional and vocational terms, or training in skills that can be applied for immediate professional benefit.

- Efficient and contemporary systems or mechanisms for handling transactions, interactions and communication with the university.

- Facilities for counselling and career guidance, for seeking redress on issues concerning academic results, discrimination or harassment.

- Greater representation in decision making and governance, accountability and optimal student services.

\section{Making Students the Principal Focus in Institutional Management of Public Universities in Ghana: The Way Forward}

In the first place, public universities should discard any misgivings about considering students as customers or clients. Coaldrake (2001) rightly suggests that students are to be treated as customers, clients or stakeholders, and then they "should be treated with respect, their rights and responsibilities should be defined and assured, and their needs and expectations at least understood and acknowledged, if not always met." (p. 81). Fomunyam (2017) corroborates this opinion by recommending that African universities need to create structures and cultures that ensure that the educational landscape caters effectively for student needs. Certainly, this is not to say that students should be allowed to dictate what topics the curriculum should include or what grades they should receive. The pertinent issue is that the universities must put in place quality assurance processes in every aspect of the educational experience of students with the view to promoting student satisfaction and enhancing the overall perceived value of education. Thus, hereafter, some of the ways by which quality in the educational process may be assured, in terms of the universities' treatment of students, are discussed. The recommendations in the discussion, however, are not to suggest that all public universities in Ghana do not have any such facilities or systems in place for promoting student satisfaction; the suggested measures are meant to be applied where there are deficiencies so as to help enhance existing systems.

\subsection{Efficient Student Enrolment Processes}

Ensuring quality services to students starts from the enrolment stage. The enrolment process should involve the planning and implementation of marketing and communication strategies to attract and admit prospective students, and to integrate newly admitted students to the university. The focus of the strategies to be adopted should be the convenience of the prospective students.

First of all, every public university must invest in an admission software which can nurture candidates throughout the admission process. This is vital because technology plays a crucial role in a smooth admission process that promotes satisfaction among prospective students. The software should be able to schedule and automate processes so as to make it easy for prospective students to make enquiries, submit applications, etc. and receive feedback.

Second, information on every public university's academic programmes, entry requirements, application processes and contacts for enquiries should be easily and readily available for prospective students. This could be in the form of a handbook, the contents of which should also be made available at the university's website. The universities may also embark on admission campaigns in the form of outreach programmes, and also ensure that they have strong social media presence as a means of attracting more prospective students.

Third, the selection process should be transparent, efficient and effective. Here again, it is necessary to have 
in place an admissions software that will automate the selection of applicants into various academic programmes, while scheduling e-mail or SMS feedbacks to candidates. It is important that applicants who do not gain admission are also given feedback on the exact reason for non-selection.

Finally, students admitted by a university need to be taken through a well-planned orientation and integration to the university. Thus, by the time students arrive on campus, the university must have come up with a programme and relevant publications designed to initiate newly admitted students into the academic, cultural and social life of the university. This programme would be the first group interaction between the students and staff where matters relating to student registration, academic counselling, campus activities and other aspects of university life are made known to the students.

\subsection{Adequate Educational Infrastructure}

Educational infrastructure is defined to include lecture theatres, auditoria, washrooms, student residential facilities, restaurants, network of roads and walkways, libraries, laboratories and equipment, access to reliable internet, on-line databases, etc. Teixeira, et al (2017) attest that the availability of these facilities and the way they are designed are crucial elements of learning environments in schools and universities. They affirm that, there is strong evidence that high quality infrastructure facilitates better teaching, improves learning outcomes, and reduces drop-out rates, among other benefits. In Ghana, however, public universities are seen to be struggling with challenges of inadequate educational infrastructure. Yelkpieri, et al. (2012) identify inadequate infrastructure and equipment as a major challenge that affect the quality of educational services and products of universities in Ghana. Evidently, this challenge persists because the increases in student enrolments continue to outweigh the marginal expansion in infrastructure over the years. Even so, we see that some public universities in Ghana continue to procure fleets of luxury vehicles in the face of inadequate lecture theatres, and there is usually a fragmented approach to investing in infrastructure. Consequently, as student enrolments continue to increase, lecture halls are usually overcrowded with some students having to stand outside lecture theatres and look through windows to listen to the lecturer and write lecture notes. Besides, library and laboratory facilities are usually overstretched, and on-campus residential facilities are woefully inadequate. In view of this situation, there is the need for the public universities to prioritize the provision of adequate infrastructure in order to ensure optimal environment for teaching and learning to the advantage of students. To this end, the public universities must adopt a systematic approach to expanding educational infrastructure even as government support continues to dwindle. University Management may institute policy to ensure that large and larger percentage of fees and other internally generated funds are set aside and invested in projects. Routine inspection, data collection and analysis would determine priority areas at any given point in time in terms of renovations, repairs, expansions, or provision of new facilities. Besides, Management of the public universities may engage in public-private partnership agreements where project delivery methods such as build-operate-transfer (BOT), build-ownoperate-transfer (BOOT), etc. may be adopted as means of expanding educational infrastructure.

\subsection{Quality Teaching}

The importance of quality teaching in motivating students cannot be overemphasized. Bess (1997) asserts that what is learned and how much is learned by students depend importantly on the quality of instruction rendered by lecturers. Olusegun (2017) corroborates this assertion by establishing that 'there is a correlation between students' motivation to learn and the quality of instruction received.' Thus, in the face of diversity of the student body and the increasing enrolment of students, it is important that public universities in Ghana ensure that, aside academic qualifications, lecturers have professional competencies in both pedagogical and andragogical skills, and also in techniques for handling large classes. Although, traditionally, university instructors are called 'lecturers' and not 'teachers', the situation in public universities in Ghana is such that the required textbooks are often either unavailable or too expensive for most students to buy, and so lecturers may well accept to 'teach' their students. Lecturers should endeavour to always make their delivery of content as clear and fluid as possible so that students can have meaningful learning experiences. More importantly lecturers should be equipped and encouraged to combine the traditional instructional approach with technological gadgets and computer application for teaching. Then also, in order to ensure that approaches to teaching and learning are in the best interest of students rather than what suit the habits of lecturers, teaching should be periodically monitored. For example, the Dean of Faculty or the Head of Department may sit in lectures of each lecturer once each semester. Regular faculty-based or departmental-based forums, which is open to all students, may also be established to share and discuss teaching and learning strategies. Besides, students should be offered opportunity to provide feedback about their experiences at the university. The institution of student evaluation of courses and teaching, in particular, would be a major headway in the quest to ensuring quality teaching. This is because student evaluations of teaching provide useful and important information on the lecturer's performance, and if student evaluations of a lecturer's teaching show that they are continually dissatisfied with their education experience with that lecturer, then this should be taken seriously and acted upon. In view of this, public universities in 
Ghana should, for each semester, enforce the use of questionnaire and other means to seek opinions of students about their learning experiences with each lecturer, and the results made available to Management for appropriate action.

\subsection{Facilities for Feedback on Student Performance and Academic Advising}

Provision of feedback to students on their performance, and the provision of advice to students with academic difficulties are essential components of any educational process. Yelkpieri, et al. (2012) affirm that "the provision of feedback helps students in their learning, because it informs them whether they are right or wrong, and therefore, helps take the necessary re-enforcement measures to help the situation." (p. 331). Hattie (1999) also describes feedback as "the most powerful single moderator that enhances achievement" (p.9). However, though feedback ought to be an important part of the student assessment process, it is often not sufficiently provided in universities. Coaldrake (2001) asserts that many higher education students are dissatisfied with the level or quality of feedback they receive and the level of interaction they experience with teaching staff during the course of their university studies. Noticeably, this assertion rightly applies to students of Ghanaian public universities where feedback have mostly been in terms of marks and grades, with scarcely any comments on the student's work. But in the face of the current large student numbers in these public universities, it is understandable that individualized written feedback or one-to-one attention at lectures is not feasible. Yelkpieri, et al. (2012) rightly observe that the advent of mass education and the limited staffing situation in the public universities in Ghana has compelled Management to resort to large class sizes, and these large class sizes adversely affect the quality of assessment of students. They indicate that one lecturer may handle over 500 students in one lecture, and this had had several implications: it makes it practically impossible to give individual attention to students who may need it; it makes it difficult to organize quizzes and class test regularly; it makes the use of essay questions for assessment most unlikely; it frustrates attempts to assess students in all topics treated; and lecturers encounter difficulties in marking class assignments and providing feedback in time. Regrettably, this issue of large class sizes continues to bedevil the public universities because of government restrictions on the recruitment of staff in spite of increasing student enrolments. And we find that the high student-lecturer ratio also has significant adverse effect on academic advising. Even though the public universities in Ghana usually make effort at providing academic advising by assigning lecturers additional responsibility as academic advisors to various student subgroups, this student service faces two major hindrances: First, the large numbers in the student subgroups makes it difficult for the academic advisor to identify students with special academic problems and provide assistance, and, second, most lecturers have heavy teaching loads and are therefore often not able to make time to meet the demands of the additional responsibility as academic advisors. In a typical case, a study on academic counselling at the University of Education, Winneba by Afful \& Reeks (2016) observed that the number of students per academic counsellor in most cases was more than 100 , and given the heavy teaching loads, some academic counsellors never met with their students throughout the semester.

In view of the foregoing issues, public universities in Ghana need to institute and enforce some remedial measures or alternative arrangements for evaluating student performances and providing feedback to students. Crucially, the high student-lecturer ratio needs to be tackled by way of prompting government to give financial clearance for the appointment of more lecturers, particularly for the general courses. Meanwhile, the most plausible ways of assessing students and providing feedback in large classes would be to administer series of objective tests for individual assessments, and assessing groups rather than individuals where the examination involve the writing of essays. Here again, the use of technology is desirable, so the universities may procure optical mark recognition (OMR) scanners and optical answer sheets for academic departments and put in place systems that can send feedback on scores to students via electronic messaging. Efforts should be made to provide feedbacks that are constructive - highlighting the strengths and weaknesses of a given work; meaningful providing guides; and timely - so as to benefit subsequent work.

The way academic advising is organized also needs to be re-examined so as to make this student service more accessible to students and more effective in addressing individual student challenges. It should be possible to assign academic advising roles to some senior administrative staff where lecturers are not enough, and routine refresher training programmes should be made available to all academic advisors. Through the refresher training, and the provision of incentive packages, the universities can ensure that the academic advisors are well equipped and motivated to take the initiative in obtaining information about the students and invite those who may have problems for discussion and assistance. The academic advisor should also be able to give students the kind of information that will increase motivation, build on existing knowledge, and help them reflect on what they have learned. And it should be expected that when students with academic problems have access to this information, they would develop an awareness of their learning, and subsequently be easily able to recognize mistakes, and eventually develop strategies for tackling weak points themselves. To verify these outcomes, it is important that the activities of academic advisors are periodically monitored, and they should be required to submit reports on 
their work.

Ideally, academic advising should not be designated as additional responsibility for teaching staff as is currently the case in public universities in Ghana, but a specialized role with staff available full-time to provide advice and assistance to students in all aspects of university life, including course choice, financial advice, accommodation, thesis writing, etc.

\subsection{Avenues for Handling Student Grievances, Complaints and Demands}

In higher education institutions, student complaints over academic or administrative matters are an important reality, and formal or informal procedures need to be developed to deal with them in a way that reflect the principles of natural justice. In fact, as demands of public universities result in higher costs to students in terms of fees, student expectations increase, and complaints will increase accordingly. Thus, in attempts to establish professional relationship with students as clients or customers, universities need to implement some processes for dealing with student complaints that are acceptable to the students. The Dearing Report (1997) on higher education in the UK recommended that universities should review their complaints policies and procedures to ensure that: they reflect the principles of natural justice; they are transparent and timely; they include procedures for reconciliation and arbitration; they include an independent, external element; and they are managed by a Senior Member of staff. The Report further indicates that the task of developing guidelines for this process should be given to the Quality Assurance Unit which should be a statutory establishment in all public universities. In view of the recommendations of the Dearing Report just outlined, it would be appropriate that public universities in Ghana ensure that their Quality Assurance Units are sufficiently resourced to enable them develop policy guidelines for dealing promptly, fairly and sufficiently with student complaints, in addition to the traditional role of ensuring high standards in teaching, learning and assessment. Again, the statutory provisions for staff-student consultative meetings at the Departmental, Faculty and Management levels, as exist in Ghanaian public universities, need to be exhaustively adhered to, and resolutions reached at these meetings should be acted on promptly. The Office of Student Affairs in the universities should also be well resourced to receive student complaints, investigate issues, support and enforce institutional policies on handling student grievances, and act as a mediator. Besides, student grievances, complaints and demands can be well noted and addressed amicably if students are given adequate representation in decision making and governance. In current situations in Ghanaian public universities, a typical Governing Council of about twenty members has only two student representatives one undergraduate student and one postgraduate student. This level of participation of about 0.1 of students on Governing Councils is not significant enough, and student influence in university governance continues to be marginal. Thus, to make for significant participation of students in institutional management of public universities, more students should be given opportunity to serve as members of the Governing Council, Finance Committee, Sports Committee, etc. that are responsible for coming up with operational guidelines, fees structure, timetabling, recreational and other policies that affect the student body. If students are allowed greater involvement in decision making, it is unlikely that they will embark on demonstrations as they will be seen as working against policies they had helped to formulate.

\section{Conclusion}

Quality in education service delivery in public universities in Ghana can be assured if policy and funds are directed in more student-centred ways. This in turn would ensure student satisfaction, promote peaceful coexistence between lecturers, administrative staff and students, and guarantee that these universities continue to remain attractive to prospective students. Particularly, the increasing demands for fees from students by public universities justifiably provide basis for requesting such universities to be more responsive to student needs and, in fairness, allow students greater representation in decision making and governance, and provide structures that allow students to take active and demanding interest in the type and quality of their university education.

\section{References}

Adu, K. H. (2009, June, 28), "Ghana: Private Higher Education on the Rise", University World News. https://www.universityworldnews.com/post.php?story=20090626115442537

Afful, D. and Reeks, P. (2016), "Enhancing Access and Use of Academic Counselling Services at the University of Education, Winneba, Winneba Campus", Journal of Research and Development in Education (JORDE) II November, 2016, pp 42-52.

Aluede, O., Jimoh, B., Agminede B. O. \& Omoregie, O. (2005), "Student Unrest in Nigerian Universities: Looking Back and Forward", Journal of Social Sciences. 10 (1): pp 17-22

Antwi, P. (2021, Jan. 8), "University of Ghana Students Embark on Wild Protest", Ghana Guardian. https://ghanaguardian.com/university-of-ghana-students-embark-on-wild-protest

Bess, J. L. (Ed.). (1997), Teaching Well and Liking It: Motivating Faculty to Teach Effectively. Baltimore, MD: John Hopkins University Press 
Coaldrake, P. (2001), "Responding to Changing Student Expectations", Journal of the Programme on Institutional Management in Higher Education Vol. 13- No. 2, pp 75-91.

Demonstrating KNUST Students Ransack VCs Office, Burn Dean's Vehicle (2018, Oct. 22), GhanaWeb. https://www.ghanaweb.com/GhanaHomePage/NewsArchive/Today-in-2018-Demonstrating-KNUSTstudents-ransack-VC-s-office-burn-Dean-s-vehicle-791934

Dogbevi, E. K. (2008, Dec. 6), "Full Cost Recovery in Ghanaian Universities-To Be or Not to Be?", Ghana BusinessNews.https://www.ghanabusinessnews.com/2008/12/06/full-cost-recovery-in-ghanaian-universities

Fomunyam, K. G. (2017), "Student Protest and the Culture of Violence at African Universities: An Inherited Ideological Trait", Yesterday and Today. No.17, Vanderbijlpark Jul. 2017. pp.38-63.

Ghana Tertiary Education Commission (2021), List of Accredited Tertiary Education Institutions. https://www.kitnes.me/kitnes/data/2021/04/27/1.20629732.pdf

Ghana National Council for Tertiary Education (2018), Statistical Report on Tertiary Education for 2016/2017 Academic Year.

GIJ Students Protest Over New Directive to Defer Course for Late Payment of Fees (2021, March 24), MyJoyOnline.com.https://www.myjoyonline.com/gij-students-protest-over-new-directive-to-defer-coursefor-late-payment-of-fees

Hattie, J. (1999), Influences on Student Learning. Aukland: University of Aukland. file://C:/Users/UEW/AppData/Local/Temp/Influences_on_Student_Learning.pdf

Kamram, M., Liang, Y. and Trines S. (2019), "Education in Ghana", World Education News + Reviews, World Education Services. https://wenr.wes.org/2019/04/education-in-ghana

Olusegun A. S. (2017), "Quality Instruction as a Motivating Factor in Higher Education", International Journal on Higher Education Vol. 6. No.4. 2017. pp 173 - 184

Shaw, C. (2013, Dec. 11), "How Should Universities Respond to Student Protests? - 10 views", The Guardian.https://www.theguardian.com/higher-education-network/blog/2013/dec/11/student-protest-howshould-management-respond

Slaughter, R and Leslie, G (1999), Academic Capitalism: Politics, Policies, and the Entrepreneurial University, Johns Hopkins University Press.

Teixeira, J., Amoroso, J. and Gresham, J. (2017), "Why Education Infrastructure Matters for Learning", Education for Global Development,

https://blogs.worldbank.org/education/why-education-infrastructure-matters-learning.

The Dearing Report (1997), "Higher Education in the Learning Society. The National Committee of Inquiry Into Higher Education", http://www.educationengland.org.uk/documents/dearing1997/dearing1997.html

University of Ghana Holds 2019 Matriculation (2019, Oct. 3), University of Ghana News. https://www.ug.edu.gh/news/university-ghana-holds-2019-matriculation-ceremony

University of Cape Coast (2016). Statutes

University of Education, Winneba (2020). Statutes

Yelkpieri, D., Namale, M., Esia-Donkoh, K., Ofosu-Dwamena, E. (2012), "Effects of Large Class Size on Effective Teaching and Learning at the Winneba Campus of the University of Education, Winneba, Ghana, US-China Education Review A 3 (2012) 319-332 